\title{
Mega Events in Sports and Crime:
}

\section{Evidence from the 1990 Football World Cup}

\section{Nadia Campaniello}

nadia.campaniello@unito.it

n.campaniello@ceris.cnr.it

Author's note: The author would like to thank Bruno Contini, Riccardo Marselli, Giovanni Mastrobuoni, Paolo Morganti and all the participants at the seminars of the Collegio Carlo Alberto, Goethe Universität and University of Sassari for their helpful comments and suggestions. 


\begin{abstract}
Despite an increasing desire to host major sport events there is almost no research that tries to identify and measure the possible negative spillovers they generate. In particular, there is limited understanding about crime responses. This paper investigates the causal relation between hosting the 1990 Football World Cup and crime rates at the province level. Using a fixed effect estimator to control for province level differences in crime, we find that hosting the Football World Cup leads to a significant increase in most property crimes (bagsnatching, pick-pocketing, shop-lifting and burglary), but only in one violent crime (intentional personal injuries).
\end{abstract}

Keywords: mega event, crime, Football World Cup, negative spillovers 


\section{Introduction}

The decision to host a mega event like the Football World Cup generates both opportunities and concerns. During these events it is likely that employment and business opportunities increase, new or improved infrastructures are developed, revenue for local governments increase, and tourism flourishes; thus giving international recognition to the city. This might even boost the feeling of being part of a community. The down side might include traffic congestion, increased crime rates, pollution, increased price of land, housing, goods and services, more car accidents, and animosity between tourists and locals (Baloglu and Deccio, 2002; Clarke, 2004; Andersson, Rustad and Solberg, 2004; Dwyer and Mules, 2005; Hiller, 1989; Burns and Mules, 1989). In this paper we focus our attention on one relevant concern of hosting a mega event: its effect on crime, which leads to social costs, typically borne by the citizen of the hosting city (Burbank, Heying and Andranovich, 2000; Preuss and Solberg, 2006).

The problem of crime during a mega event is often neglected, not investigated, and not correctly perceived by the local residents. Ohmann, Jones and Wilkes (2006) analyzed the perceived impact of the 2006 Football World Cup upon residents of one of the host provinces. Crime was one of the explored perceived negative impacts. They found that, even though crime rates did increase, just $12 \%$ of citizen correctly perceived this increase. A possible explanation for the discrepancy between the respondents' perception and police report could be lack of media coverage on these arrests.

The 1990 Football World Cup has been chosen because it is second only to the Olympics as the biggest tournament in the world, and is the last major sport event in Italy for which the data are available. Using official crime statistics of around 100 Italian provinces over several years we use the World Cup as our testing ground of criminal spillovers. 
In particular we identify provinces that hosted a game between June 8 and July 8, 1990 (the treatment group), and compare them to those provinces that did not have such mega event in place (our control group). Map 1 and Table 1 show, respectively, the provinces that hosted the football matches, the name of the stadiums, their capacity and the number of matches played.

\section{$<$ Map 1 $>$}

$<$ Table 1 $>$

We find that in 1990 there was an increase in crime rates greater in the host provinces than in the others for most property crimes, and that these effects are robust to controlling for other factors often thought to be associated with crime.

\section{Literature review}

Sport events are likely to be the scene of both premeditated and opportunistic crimes, like theft, drunkenness, disorderly behaviour and vandalism (Hall, 1992; Getz, 1997). Only few papers have looked at the relationship between hosting mega events and crime, Hall (1997) identifies a relationship between the hosting of these events and an increase in robbery, sexual and common assaults. Hall and Selwood (1989) mention the increase in petty crime during the America's Cup in 1987. Barker et al. (2002) analyze the America's Cup 2000 in Auckland, and notice that crime is a spatial phenomenon that is subject to dislocation, and the reason why it is likely to be higher in areas hosting special events is related to its tendency to cluster in areas where there is an higher concentration of tourism amenities and attractions and where security is less concentrated. These results are also in line with Billings and 
Depken (2011), who find that criminal activity increases in the vicinity of the venue when sport events are held.

Most of the studies focus on the relationship between crime and tourism finding a positive relationship between them, mainly for property crimes. In particular, Howsen and Jarrell (1990), McPheters and Stronge, (1974) and Harper (2001) find that tourism has a positive impact on the crimes of burglary, larceny and robbery and no impact on crimes against the person (murder, rape and assault).

Researchers have focused on the relationship between crime and tourism because the perceived riskiness of a city could induce tourists to choose alternative and less dangerous destinations. And it is hard to change the negative image of a city that potential tourists may hold (Dimanche and Lepetic, 1999). But this same reason represents the major shortcoming of analyses based on simple correlations between crime and tourism: if tourists avoid to visit cities with high levels of crime the estimated effect of tourism on crime is going to be biased. This study estimates how exogenously driven variation in the attractiveness of cities, in our case hosting of a World Cup game, influences crime.

\section{The economic model}

The basic assumption of the economic model of crime is that individuals maximize their expected utility and, consequently, their decision to engage or not in criminal activities is rational, and responds to the perceptions of the benefits and costs of illegal actions (see Becker, 1968; Ehrlich, 1973; Block and Heineke, 1975; Freeman, 1999, Howsen, Jarrell, 1987). Crime is regarded exactly as any other economically important activity or "industry" (Becker, 1968). Criminals, victims or representatives of law enforcement, all respond to incentives, both positive e negative, and try to maximize their wellbeing (Ehrlich, 1996; Marselli and Vannini, 1999). The approach follows the economists' usual analysis of choice 
and assumes that a person commits an offense if the expected utility he derives exceeds the utility he could get by using his time and other resources differently (Becker, 1968).

It has to be pointed out that people have different disgust for crime, but they respond to incentives, and if they rewards structure associated with an action changes, their choices are also likely to change.

The supply of crime depends on several factors, like the legitimate labour opportunities of potential criminals, the probability of arrest and penalization, and the potential criminal earnings (Freeman, 1996 and 1999).

For a given individual the expected benefits $(B)$ of committing a crime are equal to the expected payoff, that is the probability of not being apprehended $(1-p)$ times the rewards $(R)$, minus the total costs associated with planning and executing the crime $(C)$, minus the foregone wages from legitimate activities $(W)$, minus the expected punishment $(S)$ for the committed crime $(p S)$. We assume that individuals are risk neutral. A crime is going to be committed $(C r=1)$ every time the expected benefits outweigh the expected costs:

$$
C r=I[B \geq 0]=I[(1-p) R-C-W-p S \geq 0],
$$

where I[.] is an indicator function equal to one whenever the statement is true and 0 otherwise. Summing these individual decisions over individuals and time, and dividing everything by the populations leads to a crime rate that is a function of $p, R, C, W$, and $S$. Starting from these theoretical considerations we will specify and estimate a model in which the dependent variable is the number of crimes and the explanatory variables are a number of economic and social characteristics which are supposed to capture all the factors that determine the supply of crime (a detailed description is given in the following paragraph). 


\section{Data and explanatory variables}

The empirical implementation of the theoretical model described above uses the number of the reported crimes at the province level as the dependent variable. We take into consideration those crimes that could reasonably increase during a mega event, an event that usually creates a mood of general euphoria and creates more occasions of aggregation. These events tend to make cities more chaotic and typically attract several people from abroad. The crimes chosen for our investigation are mainly those against property: pick-pocketing, bagsnatching, shop-lifting, burglary in flats, theft ex car, theft on the railways, car theft, and fraud. We also take into account some crimes against the person: sexual crimes and intentional personal injuries, because football matches often bring with them a lot of violence both in and outside the stadiums. Finally we consider prostitution and drug.

The source of data is the "Statistica della delittuosità" published by ISTAT, the Italian Statistical Bureau. The data represent crimes reported to law enforcement and later transmitted to the Prefetture, which are the provincial police offices, and ultimately transmitted to the prosecutors. They started to be collected during the 1930s and have been collected since then with the exception of some years during the World War II. Most of them are just in printed and not in an electronic format (including those used in this paper).

The estimation relies on a panel of 4 years (1988-1991). Data on crime are often measured with error, largely because reporting crimes is costly to the victim, which leads to underreporting (Howsen and Jarrell, 1987). Victims very often consider it just a waste of time because, for example, the probability to recover a wallet or a bicycle stolen is very low. Underreporting is most pronounced for low-value property crime (e.g. common theft) and for crimes carrying a social stigma for the victim (e.g. rape). It means that estimates on crime might be downward biased, and even more seriously if the level of reporting changes during mega events (e.g. tourists report less than residents). But measurement errors can also go in 
the opposite direction if, for example, victims receive compensation (Ehrlich, 1996). This is confirmed by the high number of the complaints filed for car thefts, complaints that are necessary to receive insurance money (Freeman, 1999).

Since the sport mega event lasted just one month it would have been better to use monthly data to identify the relationship. These data are not available. Using yearly data, as we do, might downward bias our results.

In our research crimes are defined as the number of offences reported to law enforcement authorities. They do not correspond to the number of offenders, since an offender could have committed more than one reported crime.

As a measure of law enforcement we use the clearance rate, defined as the ratio of known offenders to all recorded crimes for each category. We don't use an aggregated measure of deterrence because the probability of detection varies considerably across crime types (Cherry and List, 2002).

The probability of detection proxies for the probability of apprehension and allows us to capture the effect of deterrence and law enforcement (Buonanno and Leonida, 2006). Deterrence essentially modifies the price of crime for all offenders.

To measure the expected gains from committing a crime (the rewards $R$ of the theoretical model) we use added value per capita, an indicator of the general level of prosperity in the provinces. Sesnowitz and Hexter (1982) use medium household income as a proxy for the expected illegal gains, because they reflect the "presence of individuals who provide good targets for thieves and thus may lead to a high gain component of the crime."

The opportunity cost of being imprisoned represents the major cost of crime, in part because of the foregone employment opportunities. The lower the unemployment rate the higher the cost of a given prison sentence to an individual; therefore, we expect the coefficient on the unemployment rate to be positive (Howsen and Jarrell, 1987). Average wage allows one to 
control for legal earnings; higher wages increase the opportunity cost of criminal behaviour. The unemployment rate and the average wage proxy for $W$ in our theoretical model.

Both average wage and added value are expressed in real 1988 prices terms using the Consumer Price Index (ISTAT and Work Histories Italian Panel ${ }^{1}$ ).

Among the socioeconomic variables we include, at the province level an index of inequality and the dependency index. Inequality might influence crime (above the role of poverty alone) because the presence of the rich may increase the returns to crime $R$ (Glaeser, 1999) and, at the same time, a strong presence of poor people, represents a potentially larger supply of criminals for offences against property (lower $W$ ). This variable has been shown to be important in explaining crime rates across countries (Fajnzylber, P., Lederman, D. and Lloayza, N. , 2002). To proxy for inequality in income we use the ratio between the number of people employed in the service sector and the total employed using WHIP data. The percentage of employed in the sector of services measures both the impact on crime of the presence of the white collar worker, and of the greater inequality in the income distribution that is often correlated to a greater development of the service sector (Marselli and Vannini, 1997). Finally, the dependency index is a demographic indicator equal to the ratio between the population older than 65 and the population between age 20 and age 64 . It is well documented that most crimes are perpetrated by youths (Imrohoroglu, Merlo, Rupert). Freeman (1999) shows that the relative arrest rate rises for teenagers, peaks for persons aged 16-18, then declines modestly with age. This might have to do with the cost of crime $C$ increasing with age. To capture any potential differential effects with respect to the location and time of the crime, in particular, hosting a World Cup game, we define some geographic and time dummies (Drakos and Kutan, 2003):

- Host province in $1990=1$ if the crime took place in 1990 and in a province that hosted the Football World Cup and 0 otherwise. This is our variable of interest. 
- Near host provinces in $1990=1$ if the crime took place in 1990 in a province whose distance from the province that hosted the Football World Cup is less than $100 \mathrm{~km}$ and 0 otherwise. This variable is supposed to capture possible spatial spillovers.

- Year $1990=1$ if the crime took place in the year 1990 and 0 otherwise. This variable is extremely important as it is supposed to capture year 1990 specific effects not captured by our regressors.

Table 2 shows the descriptive statistics used in the regression analysis.

\section{$<$ Table 2>}

The number of crimes and the economic variables have been normalized by the size of the population $P^{2}$ in order to obtain per capita values.

Added value has been divided by 1,000 to make the corresponding coefficient more easily readable.

In the Appendix there is a qualitative description of the offences we select for our analysis.

\section{Estimation model and methodology}

Our research strategy is to investigate whether there was any change in crime rates in 1990 in provinces that hosted the Football World Cup compared to what happened in other years, and compared to what happened in provinces that did not host a game. It means that we are interested in estimating the coefficient of the dummy "Host province in 1990" $\left(H_{90}\right)$, controlling for deterrence, legal and illegal gains, socio-economic variables, a 1990 dummy that captures how crime rates changed in non-hosting provinces, and province fixed effects that controls for any preexisting differences in crime rates across provinces. 
Using data on all the provinces of Italy, we use the following empirical specification:

$$
\mathrm{c}_{\mathrm{ijt}}=\beta_{0}+\mathrm{x}_{\mathrm{ijt}} \boldsymbol{\beta}+\alpha_{i}+\mu_{\mathrm{ijt}}
$$

where $c_{i j t}$ is the number of crimes per capita in the province $i$ for crime typology $j$ in year $t$, $\mathrm{x}_{\mathrm{ijt}}$ is a vector of exogenous variables, $\alpha_{i}$ are province fixed effect and $\mu_{\mathrm{ijt}}$ are "idiosyncratic errors.” To summarize, equation (2) includes observed and unobserved components.

With the introduction of the relevant variables equation (2) becomes:

$$
\mathrm{c}_{\mathrm{ijt}}=\beta_{0}+\beta_{1} \mathrm{~A}_{\mathrm{ijt}}+\beta_{2} \mathrm{~W}_{\mathrm{ijt}}+\beta_{3} \Delta \mathrm{H}_{90 \mathrm{ijt}}+\beta_{4} \mathrm{I}_{\mathrm{ijt}}+\beta_{5} \mathrm{U}_{\mathrm{ijt}}+\beta_{6} \mathrm{~S}_{\mathrm{ijt}}+\beta_{7} \mathrm{D}_{\mathrm{ijt}}+\beta_{10} \Delta \mathrm{N}_{90 \mathrm{ijt}}+
$$

$\beta_{11} \mathrm{Y}_{90 \mathrm{ijt}}+v_{\mathrm{ijt}}$

$$
\mathrm{i}=1, \ldots . . \mathrm{N} ; \mathrm{t}=1, \ldots . \mathrm{T}
$$

where the subscript $i$ represents each of the 95 provinces in Italy during the period 19881991, $c$ measures crime, $A$ is the added value, $W$ is the average wage, $\Delta H_{90}$ is the dummy for the host provinces, $I$ is the demographic dependency ratio, $U$ is the unemployment rate, $S$ is the number of people employed in the sector services over the total, $D$ is the deterrence ratio, $\Delta N_{90}$ is the dummy "near the host province", $Y_{90}$ is the dummy "year 1990 " and $v_{\mathrm{ijt}}=\alpha_{i}+\mu_{\mathrm{ijt}}$ is the composite error.

We want to test the null hypothesis that hosting a game has no effect on crime: $\beta_{3}=0$. The alternative is $\mathrm{H}_{1}: \beta_{3} \neq 0$.

(4) $\quad \beta_{3}=\left[\mathrm{E}\left(\right.\right.$ crime $\mid$ host in $\left.1990=1, x^{\prime}\right)-\mathrm{E}\left(\right.$ crime $\mid$ host in $\left.\left.1990=0, \mathrm{x}^{\prime}\right)\right]$ $\left[\mathrm{E}\left(\right.\right.$ crime $\mid$ non - host in $\left.1990=1, x^{\prime}\right)-\mathrm{E}\left(\right.$ crime $\mid$ non - host in $\left.\left.1990=0, \mathrm{x}^{\prime}\right)\right]$ 
This is the difference in crime rates in host provinces versus non host provinces in the year of the World Cup versus all the other years.

The $\alpha_{i}$ are province fixed effects which reflect all factors affecting crime that do not change over time. In other words they capture the unobservable province specific characteristics (the so called "province heterogeneity"). These might include specific geographical features, fixed differences in social capital, fixed differences in police enforcement, and different attitudes towards crime, and in reporting crimes (these differences are typically slow to change). Notice that these effects are also going to capture potential differences in sanctions $S$ across provinces (see Eq. 1). Many other factors may not be exactly constant, but they might be roughly constant over a four-year period (Wooldridge, 2002; Howsen and Jarrell, 1987).

Furthermore the presence of criminal organizations with deep and, sometimes, secular territorial roots is a peculiarity of Italy and it is very difficult to distinguish the crimes committed by single offenders from those committed by these organizations. Statistics are quite unreliable in measuring this phenomenon, so this component is mostly not observed. But given that these organizations are quite stable (they are also difficult to eradicate) fixed effects are necessary to control for their presence (Marselli and Vannini, 1999).

Moreover, even if these unobserved components were changing over time, as long as the treatment (hosting a football game) does not depend on these time-varying unobservable components the treatment effect would still be unbiased.

Nevertheless, we also show the results obtained using the random effect estimator, as opposed to our preferred fixed effect estimator. ${ }^{3}$ The choice between random and fixed effects depends on whether $\alpha_{i}$ and $x_{i t j}$ are correlated. Given that province effects are important in our context and that we want to exclude bias in our estimation of the explanatory variables due to correlation with the province effects, the random-effects estimator might not be the best choice (Neumayer, 2004). Hausman (1978) proposed a test based on the difference 
between the random effects and fixed effects estimates. Since FE is consistent when $\alpha_{i}$ and $x_{i t j}$ are correlated, but RE is inconsistent, a statistically significant difference between the two estimators is interpreted as evidence against the random effects assumption.

Tables 3-4 report the results for each type of crime analyzed using fixed and random effects along with the Hausman tests.

\section{$<$ Tables 3-4>}

In half of the regressions the Hausman test suggests the use of the fixed effects estimator. This means that the unobserved provincial component is correlated with some regressors. But overall the coefficients on hosting a game in 1990 are always quite close to each other in the two alternative specifications. The main exceptions are fraud and shop-lifting. For frauds the same result has been found by Marselli and Vannini (1997), who stress how this offence is less related than the others to organized crime. The same reasoning applies to shoplifting, a common type of juvenile offending (Oberwittler, 2004), probably related to a temporary rush of excitement, and to the enjoyable feeling of defiance and potency in just "getting away with it”, rather than to province-specific fixed effects (Bessant, 1993).

Given that the fixed effect estimators are consistent even when random effect ones are not, we are mainly going to discuss the results that are based on fixed effects specifications (Tables 3 and 4).

\section{Discussion of the estimated results}

Hosting the 1990 Football World Cup led, as expected, to a significant increase in most of crimes against property. In particular we find a significant and positive effect (whose increase at the average level of crime is indicated in parenthesis) for: pick-pocketing $(+80 \%)$, bag- 
snatching $(+51 \%)$, shop-lifting $(+29 \%)$ and burglary $(+29 \%)$. See Tables $3-4$. The crimes against property that are not affected are: theft ex car, theft on the railways, car theft and fraud.

The increased number of police forces might have prevented crimes committed in the streets for which a particular ability and more time is required (theft ex car and car theft). With respect to theft on railways, it is likely that railways were seen as strategic points, and thus were defended by a higher number of police forces.

Looking at the other offences, intentional personal injuries appears to be significantly and positively related to the fact that a province hosted the World Cup with a variation of $34 \%$, while fraud, drug, prostitution and rapes do not show any significant correlation.

The results for the intentional personal injuries are in line with the results by Rees and Schnepel (2009), who find that football college games are associated with a higher aggressive behaviour ( $+18 \%$ for vandalism), even worsened in the case of the 1990 World Cup by the presence of the Hooligans, a large group of English supporters that typically create disorder and violence around the time of a football match.

The definition of fraud is extremely wide, including also illegal activities that are not done "in the street," and it relates to "the deceiving of someone to damage him usually to obtain property or services unjustly (example are, false advertising, identity theft, false billing, forgery of documents or signatures, false insurance claim, investment frauds, etc. ," so it is not surprising that it does not change significantly due to the World Cup.

The crimes of drug and prostitution are extremely difficult to measure in official statistics, because they are essentially voluntary transactions (Levitt, 2004). Furthermore in the ISTAT statistics prostitution is defined as "exploitation and abetting of prostitution," that is only a limited definition of prostitution. The dummy used to investigate changes in crimes in the 
provinces near the hosting ones is not significantly different from zero, which means that there was no significant spillover effect on neighbouring provinces.

Finally, the dummy year 1990 isolate the variations in crimes committed in 1990 . We find significant and positive results for shop-lifting and burglary.

Let us now briefly discuss the coefficients of the remaining variables. Even if we cannot identify a relation of causality between the dependent variable and the remaining independent regressors, we can observe and describe the existence of significant correlations. Among the socioeconomic variables added value is significantly correlated with almost all the crimes against property with a positive sign. It is in line with the theoretical model that considers added value as a proxy of the opportunity of illegal gains.

The demographic dependency index is significantly related to most crimes against property (bag-snatching, theft ex car, theft on the railways and car theft) with the expected negative sign. Both unemployment and average wage represent the cost opportunities of being involved in the criminal market and we should expect a negative relationship with the different kind of crimes, but only the coefficient on unemployment is significant, and only in the random effects model, probably because the variable does not change much over time. This result is coherent with the empirical literature on this topic that did not find, if not in very simplified models, an unambiguous and significant relationship between the two phenomena (Marselli and Vannini, 2000).

Average wage is significant and positive only for car theft and (at 10 percent level) for shoplifting. It can be explained if the average wage is not only a measure of the opportunity cost to enter the criminal market, but it is also a measure of individual income, whose growth could be correlated with a larger consumption of drugs and alcoholics (Cook and Zarkin, 1985 ) and, as already discussed, with a higher propensity to commit crimes. 
The deterrence variables are significant with the expected negative sign just for intentional personal injuries and for burglary.

\section{Robustness checks}

We perform various robustness checks. In the first robustness check we added provincespecific linear time trends. We want to make sure that simple pre-existing trends are not explaining our results. Given that we have only 4 years of data the identification of the treatment effect hinges on discontinous changes in 1990 compared to 1988 , 89, and 91. Where treatment effects were significant without province-specific trends the treatment effects are still significant (in addition the treatment effect for thefts ex car becomes significant), though they tend to be lower. Given the few number of years of trend is based on this is not very surprising. (Tables 5 and $5 a$ ).

We also performed two additional analyses that have to do with the presence of tourists. Tourists, whether foreign or not, might be more or less likely to be victimized during sports events than locals. Therefore we collected data on the presence of tourists from the Statistiche del turismo, ISTAT, and estimated the model adding tourists (both domestic and foreigner) and an interaction between the host province 1990 dummy variable and the number of tourists.

Tourist flows, both foreign and domestic measure the daily presence of tourists, that is the number of arrivals times the days of stay. Unfortunately, we have to use yearly figures of tourist flows since monthly ones are not available. A large number of tourists in an area increases the number of unidentified people in an area, potential suspects, making it easier to escape apprehension, but more tourists are also potential victims (Howsen and Jarrell, 1990). Finally, the social consequences for victimizing tourists are very low, because their extraneousness to the local community prevents the criminal to incur the other residents', 
who may be relatives of friends of the victim, hostilities (Chesney-Lind and Lind, 1986). Foreign and domestic tourists are per capita and have been divided by 1,000 to make their coefficient more easily readable. The estimated treatment effects do not vary much when we control for yearly presence of turists and are shown in Table 5 and $5 \mathrm{a}$. The same is true when we interact tourists with the hosting province in 1990. In this case the interaction shows that the higher the number of tourists in the hosting city in 1990, the lower the crimes of bagsnatching, shop lifting and theft in the railways.

$<$ Tables 5>

\section{Conclusions}

We identify the causal effect of hosting one of the most important sport events, a Football World Cup, on several crime categories.

We find evidence of a sizeable positive relationship between hosting a game and most crimes against property. The identification is based on the assumption that, conditional on several time-varying characteristics of the provinces, in the absence of the World Cup provinces that hosted soccer games would have had trends in crime like provinces that did not host a game. Future research will try to evaluate the social cost of these additional crimes, in order to assist city officials that need to decide whether to host a mega event.

On the external validity of this analysis, the treatment effect might certainly be very different depending on the country involved. The United States, for example, hosted the World Cup in 1994 but football is way less popular there than it is in Europe or in South America. One would thus imagine that the effects on crime might be very different as well. Replicating this analysis using other countries (the US in 1994, France in 1998, South Korea and Japan in 
2002, Germany in 2006, South Africa 2010) would thus be a natural follow-up study, but goes beyond the scope of this work. 
Map 1- Host cities of the 1990 Football World Cup

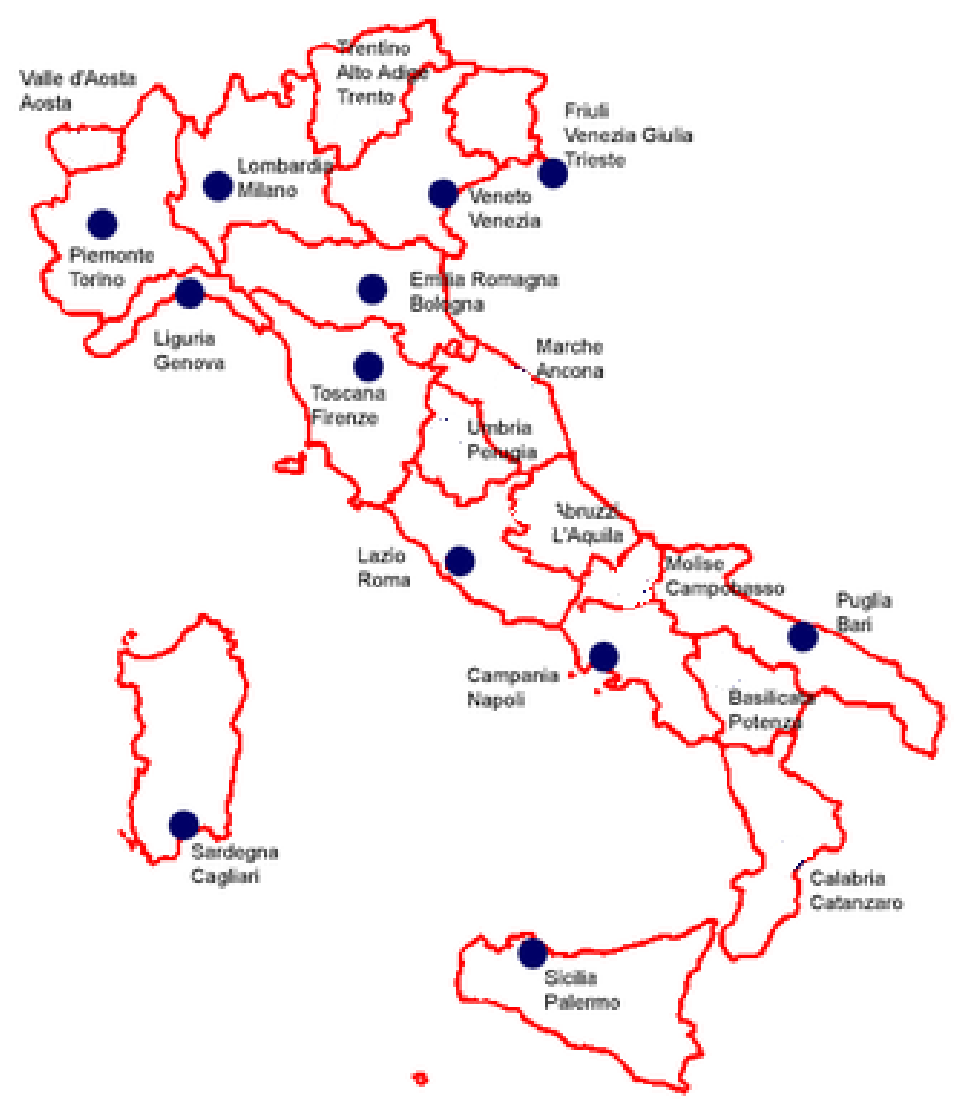


Table 1- The Stadiums, their capacity and the matches played

\begin{tabular}{llcc}
\hline City & Stadium & Capacity & Matches \\
\hline Bari & Stadio "San Nicola" & 58,000 & 5 \\
Bologna & Stadio "R. Dall'Ara" & 39,500 & 4 \\
Cagliari & Stadio "Sant'Elia" & 40,000 & 3 \\
Firenze & Stadio “A. Franchi" & 47,500 & 4 \\
Genova & Stadio "L. Ferraris" - Marassi & 40,000 & 4 \\
Milano & Stadio "G. Meazza"- San Siro & 85,500 & 6 \\
Napoli & Stadio "San Paolo" & 73,000 & 5 \\
Palermo & Stadio "R. Barbera" - La Favorita & 37,500 & 3 \\
Roma & Stadio “Olimpico" & 83,000 & 6 \\
Torino & Stadio "delle Alpi" & 69,000 & 5 \\
Udine & Stadio "Friuli" & 42,000 & 3 \\
Verona & Stadio "M. Bentegodi" & 42,500 & 4 \\
\hline
\end{tabular}


Table 2. Descriptive information on variables

\begin{tabular}{|c|c|c|c|c|c|}
\hline Variable & Obs & Mean & Std. Dev. & Min & Max \\
\hline Rapes & 343 & 0.014 & 0.009 & 0.000 & 0.071 \\
\hline Intentional personal injuries & 380 & 0.149 & 0.140 & 0.001 & 0.911 \\
\hline Pickpocketing & 380 & 0.890 & 1.671 & 0.000 & 10.65 \\
\hline Bag-snatching & 379 & 0.428 & 0.618 & 0.000 & 3.321 \\
\hline Shop-lifting & 380 & 0.488 & 0.346 & 0.015 & 2.040 \\
\hline Burglary & 380 & 1.360 & 0.899 & 0.073 & 6.400 \\
\hline Theft ex car & 380 & 3.169 & 3.284 & 0.258 & 18.48 \\
\hline Theft on the railways & 376 & 0.130 & 0.259 & 0.000 & 1.773 \\
\hline Car theft & 380 & 1.594 & 2.037 & 0.100 & 10.881 \\
\hline Fraud & 380 & 0.251 & 0.242 & 0.010 & 2.474 \\
\hline Drugs & 380 & .270 & .242 & .003 & 1.578 \\
\hline Prostitution & 372 & .011 & .0303 & 0 & .427 \\
\hline Added value & 380 & 18946.20 & 4682.85 & 9817.19 & 28696.31 \\
\hline Average wage & 380 & 9719.11 & 1072.72 & 5782.42 & 12935.50 \\
\hline Host province in 1990 & 380 & 0.032 & 0.175 & 0.000 & 1.000 \\
\hline Dependency Index & 380 & 47.878 & 4.073 & 37.620 & 56.760 \\
\hline Unemployment Rate & 380 & 11.437 & 7.263 & 1.951 & 33.962 \\
\hline Employed in Services/Total employed & 380 & 34.16 & 9.32 & 18.00 & 68.80 \\
\hline Pr. of detection for intentional personal injuries & 327 & 0.826 & 0.201 & 0.000 & 1.000 \\
\hline Pr. of detection for Pickpocketing & 380 & 0.864 & 0.127 & 0.296 & 1.125 \\
\hline Pr. of detection for bag snatching & 380 & 0.045 & 0.061 & 0.000 & 0.500 \\
\hline Pr. of detection for shop-lifting & 378 & 0.123 & 0.122 & 0.000 & 1.000 \\
\hline Pr. of detection for burglary & 380 & 0.178 & 0.082 & 0.043 & 0.449 \\
\hline Pr. of detection for theft ex car & 380 & 0.084 & 0.042 & 0.018 & 0.357 \\
\hline Pr. of detection for theft on the railways & 364 & 0.090 & 0.145 & 0.000 & 1.000 \\
\hline Pr. of detection for car theft & 380 & 0.091 & 0.063 & 0.000 & 0.400 \\
\hline Pr. of detection for fraud & 380 & 0.747 & 0.133 & 0.237 & 0.991 \\
\hline Pr. of detection for Drugs & 380 & 0.961 & 0.053 & 0.583 & 1.050 \\
\hline Pr. of detection for prostitution & 330 & 0.926 & 0.168 & 0.000 & 1.154 \\
\hline Foreign tourists & 380 & 1770.45 & 3978.73 & 9.48 & 39714.73 \\
\hline Domestic tourists & 380 & 5171.09 & 7993.31 & 311.56 & 55249.75 \\
\hline Near host provinces & 380 & 0.200 & 0.401 & 0.000 & 1.000 \\
\hline Near host provinces in 1990 & 380 & 0.050 & 0.218 & 0.000 & 1.000 \\
\hline Year 1990 & 380 & 0.250 & 0.434 & 0.000 & 1.000 \\
\hline
\end{tabular}

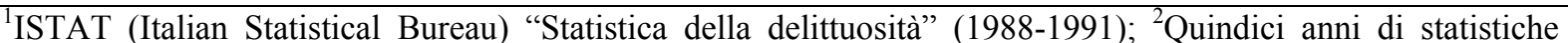
provinciali (edited by Confindustria-IPI, Editore SIPI, Roma, 2000); ${ }^{3}$ ISTAT "Statistiche del turismo" (19881991) 
Table 3. Property crimes in the host provinces of the 1990 Football World Cup with FE

\begin{tabular}{|c|c|c|c|c|c|c|c|}
\hline & \multicolumn{7}{|c|}{ Dependant variables } \\
\hline & $\begin{array}{c}\text { Pick- } \\
\text { pocketing }\end{array}$ & $\begin{array}{c}\text { Bag- } \\
\text { snatching }\end{array}$ & Shop-lifting & Burglary & Theft ex car & $\begin{array}{l}\text { Theft on the } \\
\text { railways }\end{array}$ & Car theft \\
\hline Host province in 1990 & $\begin{array}{c}0.712 \\
(4.64)^{* *}\end{array}$ & $\begin{array}{c}0.218 \\
(3.17)^{* *}\end{array}$ & $\begin{array}{c}0.14 \\
(2.90)^{* *}\end{array}$ & $\begin{array}{c}0.4 \\
(2.81)^{* *}\end{array}$ & $\begin{array}{l}0.391 \\
(1.56)\end{array}$ & $\begin{array}{l}-0.04 \\
(0.94)\end{array}$ & $\begin{array}{l}0.281 \\
(1.34)\end{array}$ \\
\hline Added value & $\begin{array}{c}0.237 \\
(4.14)^{* *}\end{array}$ & $\begin{array}{c}0.06 \\
(2.33)^{*}\end{array}$ & $\begin{array}{c}0.065 \\
(3.57)^{* *}\end{array}$ & $\begin{array}{c}0.197 \\
(3.72)^{* *}\end{array}$ & $\begin{array}{l}0.204 \\
(2.20)^{*}\end{array}$ & $\begin{array}{l}-0.014 \\
(0.83)\end{array}$ & $\begin{array}{c}0.15 \\
(1.93)+\end{array}$ \\
\hline Average wage & $\begin{array}{l}-0.109 \\
(1.08)\end{array}$ & $\begin{array}{l}0.031 \\
(0.67)\end{array}$ & $\begin{array}{c}0.058 \\
(1.83)^{+}\end{array}$ & $\begin{array}{l}0.101 \\
(1.07)\end{array}$ & $\begin{array}{l}-0.23 \\
(1.40)\end{array}$ & $\begin{array}{l}-0.02 \\
(0.56)\end{array}$ & $\begin{array}{c}-0.42 \\
(3.04)^{* *}\end{array}$ \\
\hline Dependency Index & $\begin{array}{l}0.083 \\
(1.31)\end{array}$ & $\begin{array}{l}-0.058 \\
(2.04)^{*}\end{array}$ & $\begin{array}{l}0.008 \\
(0.42)\end{array}$ & $\begin{array}{l}0.049 \\
(0.82)\end{array}$ & $\begin{array}{l}-0.217 \\
(2.10)^{*}\end{array}$ & $\begin{array}{c}-0.03 \\
(1.69)^{+}\end{array}$ & $\begin{array}{c}-0.519 \\
(6.00)^{* *}\end{array}$ \\
\hline Unemployment Rate & $\begin{array}{l}-0.003 \\
(0.15)\end{array}$ & $\begin{array}{c}0 \\
(0.01)\end{array}$ & $\begin{array}{l}-0.009 \\
(1.39)\end{array}$ & $\begin{array}{l}-0.03 \\
(1.56)\end{array}$ & $\begin{array}{l}-0.053 \\
(1.57)\end{array}$ & $\begin{array}{l}-0.004 \\
(0.65)\end{array}$ & $\begin{array}{l}0.004 \\
(0.15)\end{array}$ \\
\hline $\begin{array}{l}\text { Empl. in Services/Tot. } \\
\text { Empl. }\end{array}$ & $\begin{array}{l}-0.016 \\
(0.91)\end{array}$ & $\begin{array}{l}-0.004 \\
(0.46)\end{array}$ & $\begin{array}{c}0 \\
(0.03)\end{array}$ & $\begin{array}{c}-0.047 \\
(2.87)^{* *}\end{array}$ & $\begin{array}{l}-0.066 \\
(2.31)^{*}\end{array}$ & $\begin{array}{l}0.002 \\
(0.32)\end{array}$ & $\begin{array}{l}-0.019 \\
(0.81)\end{array}$ \\
\hline Probability of detection & $\begin{array}{l}0.017 \\
(0.04)\end{array}$ & $\begin{array}{l}-0.026 \\
(0.22)\end{array}$ & $\begin{array}{l}-0.086 \\
(0.50)\end{array}$ & $\begin{array}{c}-1.98 \\
(2.12)^{*}\end{array}$ & $\begin{array}{l}-2.122 \\
(1.23)\end{array}$ & $\begin{array}{l}-0.022 \\
(0.38)\end{array}$ & $\begin{array}{l}1.131 \\
(1.11)\end{array}$ \\
\hline Near host provinces in 1990 & $\begin{array}{l}-0.05 \\
(0.39)\end{array}$ & $\begin{array}{l}0.002 \\
(0.03)\end{array}$ & $\begin{array}{l}-0.009 \\
(0.23)\end{array}$ & $\begin{array}{l}0.067 \\
(0.57)\end{array}$ & $\begin{array}{l}-0.12 \\
(0.57)\end{array}$ & $\begin{array}{l}0.012 \\
(0.34)\end{array}$ & $\begin{array}{l}-0.033 \\
(0.19)\end{array}$ \\
\hline Year 1990 & $\begin{array}{l}0.073 \\
(1.12)\end{array}$ & $\begin{array}{l}0.032 \\
(1.09)\end{array}$ & $\begin{array}{c}0.05 \\
(2.42)^{*}\end{array}$ & $\begin{array}{c}0.17 \\
(2.80)^{* *}\end{array}$ & $\begin{array}{l}0.166 \\
(1.56)\end{array}$ & $\begin{array}{l}-0.002 \\
(0.12)\end{array}$ & $\begin{array}{l}0.085 \\
(0.96)\end{array}$ \\
\hline Constant & $\begin{array}{c}-5.951 \\
(1.72)+\end{array}$ & $\begin{array}{l}1.888 \\
(1.21)\end{array}$ & $\begin{array}{l}-1.612 \\
(1.47)\end{array}$ & $\begin{array}{l}-3.636 \\
(1.13)\end{array}$ & $\begin{array}{l}10.352 \\
(1.83)^{+}\end{array}$ & $\begin{array}{c}2.012 \\
(2.02)^{*}\end{array}$ & $\begin{array}{c}19.994 \\
(4.22)^{* *}\end{array}$ \\
\hline Observations & 380 & 378 & 380 & 380 & 380 & 364 & 380 \\
\hline
\end{tabular}


Table 3a. Other crimes in the host provinces of the 1990 Football World Cup with FE

\begin{tabular}{|c|c|c|c|c|c|}
\hline & \multicolumn{5}{|c|}{ Dependant variables } \\
\hline & Fraud & Rapes & $\begin{array}{c}\text { Personal } \\
\text { intentional } \\
\text { injuries }\end{array}$ & Drugs & Prostitution \\
\hline \multirow[t]{2}{*}{ Host province in 1990} & 0.045 & 0.002 & 0.05 & -0.045 & -0.003 \\
\hline & $(0.68)$ & $(0.72)$ & $(2.01)^{*}$ & $(1.13)$ & $(0.29)$ \\
\hline \multirow[t]{2}{*}{ Added value } & -0.025 & -0.002 & 0.014 & 0.026 & 0.008 \\
\hline & $(1.03)$ & $(1.35)$ & (1.47) & $(1.76)^{+}$ & $(1.65)^{+}$ \\
\hline \multirow[t]{2}{*}{ Average wage } & 0.054 & 0.003 & -0.009 & 0.016 & -0.007 \\
\hline & $(1.23)$ & $(1.65)$ & $(0.56)$ & $(0.63)$ & $(0.83)$ \\
\hline \multirow[t]{2}{*}{ Dependency Index } & -0.009 & 0.003 & 0.014 & 0 & -0.002 \\
\hline & $(0.32)$ & $(2.26)^{*}$ & $(1.33)$ & $(0.01)$ & $(0.31)$ \\
\hline \multirow[t]{2}{*}{ Unemployment Rate } & -0.001 & -0.001 & 0 & -0.003 & 0.002 \\
\hline & $(0.08)$ & $(2.06)^{*}$ & $(0.04)$ & $(0.57)$ & $(1.24)$ \\
\hline \multirow{2}{*}{$\begin{array}{l}\text { Empl. in Services/Tot. } \\
\text { Empl. }\end{array}$} & 0.001 & 0 & -0.006 & 0.004 & 0 \\
\hline & $(0.17)$ & $(0.47)$ & $(1.97)^{*}$ & $(0.93)$ & $(0.02)$ \\
\hline \multirow{2}{*}{$\begin{array}{l}\text { Probability of } \\
\text { detection }\end{array}$} & 0.048 & -0.001 & -0.231 & 0.029 & -0.003 \\
\hline & $(0.37)$ & $(0.30)$ & $(5.32)^{* *}$ & $(0.19)$ & $(0.25)$ \\
\hline \multirow{2}{*}{$\begin{array}{l}\text { Near host provinces in } \\
1990\end{array}$} & -0.032 & 0.001 & -0.006 & -0.02 & -0.007 \\
\hline & $(0.57)$ & $(0.42)$ & $(0.28)$ & $(0.63)$ & $(0.64)$ \\
\hline \multirow[t]{2}{*}{ Year 1990} & -0.042 & -0.002 & -0.007 & -0.035 & -0.002 \\
\hline & $(1.45)$ & $(1.51)$ & $(0.63)$ & $(2.11)^{*}$ & $(0.37)$ \\
\hline \multirow[t]{2}{*}{ Constant } & 0.564 & -0.125 & -0.288 & -0.505 & -0.012 \\
\hline & $(0.38)$ & $(1.73)^{+}$ & $(0.50)$ & $(0.57)$ & $(0.04)$ \\
\hline Observations & 380 & 327 & 380 & 380 & 330 \\
\hline
\end{tabular}


Table 4. Property crimes in the host provinces of the 1990 Football World Cup with RE

\begin{tabular}{|c|c|c|c|c|c|c|c|}
\hline & \multicolumn{7}{|c|}{ Dependant variables } \\
\hline & $\begin{array}{c}\text { Pick- } \\
\text { pocketing }\end{array}$ & Bag-snatching & $\begin{array}{l}\text { Shop- } \\
\text { lifting }\end{array}$ & Burglary & Theft ex car & $\begin{array}{l}\text { Theft on the } \\
\text { railways }\end{array}$ & Car theft \\
\hline \multirow[t]{2}{*}{ Host province in 1990} & 0.71 & 0.231 & 0.144 & 0.412 & 0.433 & -0.041 & 0.367 \\
\hline & $(4.53)^{* *}$ & $(3.30)^{* *}$ & $(2.97)^{* *}$ & $(2.83)^{* *}$ & $(1.69)^{+}$ & $(0.94)$ & $(1.63)$ \\
\hline \multirow[t]{2}{*}{ Added value } & 0.153 & -0.012 & 0.034 & 0.083 & -0.038 & -0.001 & -0.094 \\
\hline & $(4.21)^{* *}$ & $(0.76)$ & $(3.45)^{* *}$ & $(3.01)^{* *}$ & $(0.59)$ & $(0.15)$ & $(1.89)^{+}$ \\
\hline \multirow[t]{2}{*}{ Average wage } & -0.008 & 0.133 & 0.07 & 0.103 & 0.547 & 0.007 & 0.75 \\
\hline & $(0.11)$ & $(4.51)^{* *}$ & $(3.65)^{* *}$ & $(1.93)^{+}$ & $(4.55)^{* *}$ & $(0.44)$ & $(7.79)^{* *}$ \\
\hline \multirow[t]{2}{*}{ Host province } & 2.66 & 0.813 & 0.264 & 0.564 & 5.565 & 0.295 & 2.454 \\
\hline & $(6.95)^{* *}$ & $(5.12)^{* *}$ & $(2.87)^{* *}$ & $(2.35)^{*}$ & $(7.23)^{* *}$ & $(4.55)^{* *}$ & $(4.97)^{* *}$ \\
\hline \multirow[t]{2}{*}{ Dependency Index } & 0.036 & -0.016 & 0.009 & 0.031 & -0.107 & -0.021 & -0.142 \\
\hline & $(1.03)$ & $(1.05)$ & $(0.97)$ & $(1.28)$ & $(1.62)$ & $(3.06)^{* *}$ & $(3.02)^{* *}$ \\
\hline \multirow[t]{2}{*}{ Unemployment Rate } & 0.025 & 0.009 & -0.002 & -0.014 & 0.005 & 0.001 & 0.041 \\
\hline & $(1.40)$ & $(1.20)$ & $(0.31)$ & $(0.95)$ & $(0.16)$ & $(0.13)$ & $(1.65)+$ \\
\hline \multirow[t]{2}{*}{$\begin{array}{l}\text { Empl. in Services/Tot. } \\
\text { Empl. }\end{array}$} & 0.023 & -0.002 & 0.004 & -0.005 & -0.017 & 0.003 & -0.007 \\
\hline & $(2.14)^{*}$ & $(0.38)$ & (1.61) & $(0.71)$ & $(0.86)$ & $(1.70)^{+}$ & $(0.51)$ \\
\hline \multirow[t]{2}{*}{ Probability of detection } & -0.254 & -0.132 & -0.255 & -3.143 & -3.63 & -0.046 & -1.224 \\
\hline & $(0.54)$ & $(1.13)$ & $(1.61)$ & $(3.60)^{* *}$ & $(2.09)^{*}$ & $(0.84)$ & $(1.21)$ \\
\hline \multirow[t]{2}{*}{$\begin{array}{l}\text { Near host provinces in } \\
1990\end{array}$} & -0.027 & 0.008 & -0.004 & 0.092 & -0.061 & 0.013 & 0.001 \\
\hline & $(0.21)$ & $(0.13)$ & $(0.11)$ & $(0.76)$ & $(0.28)$ & $(0.35)$ & $(0.00)$ \\
\hline \multirow[t]{2}{*}{ Near host province } & -0.058 & 0.058 & -0.016 & -0.16 & -0.164 & -0.011 & -0.09 \\
\hline & $(0.19)$ & $(0.46)$ & $(0.22)$ & $(0.85)$ & $(0.26)$ & $(0.21)$ & $(0.23)$ \\
\hline \multirow[t]{2}{*}{ Year 1990} & 0.049 & 0.053 & 0.053 & 0.15 & 0.196 & -0.005 & 0.19 \\
\hline & $(0.76)$ & $(1.86)^{+}$ & $(2.64)^{* *}$ & $(2.54)^{*}$ & $(1.84)^{+}$ & $(0.28)$ & $(2.07)^{*}$ \\
\hline \multirow[t]{2}{*}{ Constant } & -5.101 & -0.043 & -1.405 & -2.197 & 3.688 & 0.934 & 2.451 \\
\hline & $(2.44)^{*}$ & $(0.05)$ & $(2.52)^{*}$ & $(1.46)$ & $(0.96)$ & $(2.20)^{*}$ & $(0.87)$ \\
\hline Observations & 380 & 378 & 380 & 380 & 380 & 364 & 380 \\
\hline Hausman test (Prob>chi2) & 0.030 & 0.999 & 0.135 & 0.002 & 0.013 & 0.216 & 0.000 \\
\hline
\end{tabular}


Table 4a. Other crimes in the host provinces of the 1990 Football World Cup with RE

\begin{tabular}{|c|c|c|c|c|c|}
\hline & & & Dependant variable & & \\
\hline & Fraud & Rapes & $\begin{array}{c}\text { Personal intentional } \\
\text { injuries }\end{array}$ & Drugs & Prostitution \\
\hline Host province in 1990 & $\begin{array}{l}0.044 \\
(0.67)\end{array}$ & $\begin{array}{l}0.002 \\
(0.67)\end{array}$ & $\begin{array}{c}0.049 \\
(1.94)^{+}\end{array}$ & $\begin{array}{l}-0.047 \\
(1.19)\end{array}$ & $\begin{array}{l}-0.002 \\
(0.15)\end{array}$ \\
\hline Added value & $\begin{array}{l}0.008 \\
(0.93)\end{array}$ & $\begin{array}{c}0 \\
(0.29)\end{array}$ & $\begin{array}{l}0.007 \\
(1.60)\end{array}$ & $\begin{array}{c}0.014 \\
(1.85)^{+}\end{array}$ & $\begin{array}{c}0 \\
(0.46)\end{array}$ \\
\hline Average wage & $\begin{array}{l}-0.008 \\
(0.47)\end{array}$ & $\begin{array}{c}0 \\
(0.48)\end{array}$ & $\begin{array}{l}-0.014 \\
(1.58)\end{array}$ & $\begin{array}{l}0.018 \\
(1.29)\end{array}$ & $\begin{array}{l}-0.001 \\
(0.63)\end{array}$ \\
\hline Host province & $\begin{array}{l}0.074 \\
(1.15)\end{array}$ & $\begin{array}{l}-0.001 \\
(0.35)\end{array}$ & $\begin{array}{l}0.003 \\
(0.08)\end{array}$ & $\begin{array}{c}0.146 \\
(2.21)^{*}\end{array}$ & $\begin{array}{l}0.007 \\
(1.06)\end{array}$ \\
\hline Dependency Index & $\begin{array}{l}-0.007 \\
(0.97)\end{array}$ & $\begin{array}{c}0 \\
(1.41)\end{array}$ & $\begin{array}{l}0.006 \\
(1.37)\end{array}$ & $\begin{array}{l}-0.009 \\
(1.27)\end{array}$ & $\begin{array}{c}0.001 \\
(1.78)^{+}\end{array}$ \\
\hline Unemployment Rate & $\begin{array}{l}0.001 \\
(0.11)\end{array}$ & $\begin{array}{c}0 \\
(0.15)\end{array}$ & $\begin{array}{l}-0.001 \\
(0.27)\end{array}$ & $\begin{array}{l}-0.002 \\
(0.43)\end{array}$ & $\begin{array}{l}-0.001 \\
(1.29)\end{array}$ \\
\hline Empl. in Services/Tot. Empl. & $\begin{array}{l}0.001 \\
(0.51)\end{array}$ & $\begin{array}{c}0 \\
(2.36)^{*}\end{array}$ & $\begin{array}{l}0.001 \\
(0.54)\end{array}$ & $\begin{array}{l}0.003 \\
(1.35)\end{array}$ & $\begin{array}{c}0 \\
(0.70)\end{array}$ \\
\hline Probability of detection & $\begin{array}{l}0.065 \\
(0.62)\end{array}$ & $\begin{array}{c}0 \\
(0.05)\end{array}$ & $\begin{array}{c}-0.269 \\
(6.50)^{* *}\end{array}$ & $\begin{array}{l}-0.025 \\
(0.17)\end{array}$ & $\begin{array}{l}-0.002 \\
(0.17)\end{array}$ \\
\hline Near host provinces in 1990 & $\begin{array}{l}-0.036 \\
(0.66)\end{array}$ & $\begin{array}{l}0.002 \\
(0.67)\end{array}$ & $\begin{array}{l}-0.003 \\
(0.15)\end{array}$ & $\begin{array}{l}-0.02 \\
(0.62)\end{array}$ & $\begin{array}{l}-0.004 \\
(0.37)\end{array}$ \\
\hline Near host province & $\begin{array}{l}0.014 \\
(0.27)\end{array}$ & $\begin{array}{c}0 \\
(0.05)\end{array}$ & $\begin{array}{c}0.04 \\
(1.28)\end{array}$ & $\begin{array}{l}-0.033 \\
(0.63)\end{array}$ & $\begin{array}{l}0.003 \\
(0.66)\end{array}$ \\
\hline Year 1990 & $\begin{array}{l}-0.042 \\
(1.56)\end{array}$ & $\begin{array}{l}-0.003 \\
(2.26)^{*}\end{array}$ & $\begin{array}{l}-0.015 \\
(1.44)\end{array}$ & $\begin{array}{c}-0.031 \\
(1.94)^{+}\end{array}$ & $\begin{array}{l}-0.002 \\
(0.41)\end{array}$ \\
\hline Constant & $\begin{array}{l}0.404 \\
(0.89)\end{array}$ & $\begin{array}{l}-0.013 \\
(0.77)\end{array}$ & $\begin{array}{l}0.087 \\
(0.33)\end{array}$ & $\begin{array}{l}0.187 \\
(0.44)\end{array}$ & $\begin{array}{l}-0.022 \\
(0.47)\end{array}$ \\
\hline Observations & 380 & 327 & 380 & 380 & 330 \\
\hline Hausman test (Prob>chi2) & 0.900 & $\infty$ & 0.059 & 0.601 & 0.845 \\
\hline
\end{tabular}


Table 5. Robustness checks for property crimes

\begin{tabular}{|c|c|c|c|c|c|c|c|}
\hline & \multicolumn{7}{|c|}{ Dependant variables } \\
\hline & $\begin{array}{c}\text { Pick- } \\
\text { pocketing }\end{array}$ & $\begin{array}{c}\text { Bag- } \\
\text { snatching }\end{array}$ & $\begin{array}{l}\text { Shop- } \\
\text { lifting }\end{array}$ & Burglary & $\begin{array}{c}\text { Theft ex } \\
\text { car }\end{array}$ & $\begin{array}{c}\text { Theft on } \\
\text { the } \\
\text { railways }\end{array}$ & Car theft \\
\hline \multicolumn{8}{|c|}{ Province-specific linear time trends } \\
\hline Host province in 1990 & 0.389 & 0.129 & 0.076 & 0.248 & 0.278 & -0.017 & 0.017 \\
\hline & $(4.25)^{* *}$ & $(2.99)^{* *}$ & $(2.50)^{*}$ & $(2.72)^{* *}$ & $(1.98)^{*}$ & $(0.36)$ & $(0.14)$ \\
\hline \multicolumn{8}{|c|}{ Domestic and foreigner tourists } \\
\hline Host province in 1990 & 0.695 & 0.212 & 0.143 & 0.392 & 0.386 & -0.036 & 0.223 \\
\hline & $(4.50)^{* *}$ & $(3.06)^{* *}$ & $(2.95)^{* *}$ & $(2.72)^{* *}$ & $(1.53)$ & $(0.83)$ & $(1.07)$ \\
\hline \multicolumn{8}{|c|}{ Interaction tourists -hosting province } \\
\hline Host province in 1990 & 0.534 & 0.369 & 0.302 & 0.528 & 0.664 & 0.072 & 0.439 \\
\hline \multirow{3}{*}{$\begin{array}{l}\text { Interaction tourists -hosting } \\
\text { province } 1990\end{array}$} & $(1.92)^{+}$ & $(2.98)^{* *}$ & $(3.54)^{* *}$ & $(2.07)^{*}$ & $(1.47)$ & $(0.92)$ & $(1.18)$ \\
\hline & 0.028 & -0.052 & -0.051 & -0.068 & -0.116 & -0.034 & -0.088 \\
\hline & $-(0.44)$ & $(1.85)^{+}$ & $(2.63)^{* *}$ & $-(1.17)$ & $-(1.13)$ & $(1.92)^{+}$ & $-(1.04)$ \\
\hline
\end{tabular}

Note: We did a robustness check regressing different types of property crimes on the host provinces of the 1990 Football World Cup using province-specific linear time trends, introducing domestic and foreigner tourists and, finally, interacting tourists with the hosting cities. Each section represents different regressions..Absolute value of $\mathrm{t}$ statistics are in parentheses: + significant at $10 \%$; ${ }^{*}$ significant at $5 \%$; ** significant at $1 \%$.

Table 5a. Robustness checks for other crimes

\begin{tabular}{|c|c|c|c|c|c|}
\hline & \multicolumn{5}{|c|}{ Dependant variables } \\
\hline & Fraud & Rapes & $\begin{array}{l}\text { Personal intentional } \\
\text { injuries }\end{array}$ & Drugs & Prostitution \\
\hline \multicolumn{6}{|c|}{ Province-specific linear time trends } \\
\hline \multirow[t]{2}{*}{ Host province in 1990} & 0.003 & 0.004 & 0.038 & -0.038 & -0.001 \\
\hline & $(0.05)$ & $(1.12)$ & $(1.86)^{+}$ & $(1.12)$ & $(0.11)$ \\
\hline \multicolumn{6}{|c|}{ Domestic and foreigner tourists } \\
\hline \multirow[t]{2}{*}{ Host province in 1990} & 0.046 & 0.002 & 0.059 & -0.042 & 0 \\
\hline & $(0.69)$ & $(0.87)$ & $(2.40)^{*}$ & $(1.05)$ & $(0.02)$ \\
\hline \multicolumn{6}{|c|}{ Interaction tourists -hosting province } \\
\hline \multirow[t]{2}{*}{ Host province in 1990} & 0.09 & -0.001 & 0.099 & -0.009 & -0.003 \\
\hline & $(0.75)$ & $(0.16)$ & $(2.25)^{*}$ & $(0.12)$ & $(0.16)$ \\
\hline \multirow[t]{2}{*}{$\begin{array}{l}\text { Interaction tourists -hosting province } \\
1990\end{array}$} & -0.012 & 0.001 & -0.015 & -0.011 & 0.001 \\
\hline & $-(0.44)$ & $-(0.76)$ & -1.51 & $-(0.70)$ & $-(0.20)$ \\
\hline
\end{tabular}

Note: We did a robustness check regressing different types of non property crimes on the host provinces of the 1990 Football World Cup using province-specific linear time trends, introducing domestic and foreigner tourists and, finally, interacting tourists with the hosting cities. Each section represents different regressions. Absolute value of $\mathrm{t}$ statistics are in parentheses: + significant at $10 \%$; $*$ significant at $5 \%$; ** significant at $1 \%$. 


\section{Data Appendix - A qualitative description of the crimes}

\begin{tabular}{|c|c|}
\hline Variable & Description \\
\hline Rapes & $\begin{array}{l}\text { To compel a person through physical force or duress to have sexual } \\
\text { intercourse }\end{array}$ \\
\hline Intentional personal injuries & To commit physical injuries with guilty mind \\
\hline Pick-pocketing & To steal from the pockets of others in public places \\
\hline Bag-snatching: & $\begin{array}{l}\text { To take an item the victim is wearing or carrying from the victim using } \\
\text { (slight) force }\end{array}$ \\
\hline Shop-lifting & To steal items from shops excluding theft by employees \\
\hline Burglary & $\begin{array}{l}\text { To enter any building or part of a building as a trespasser with the intention to } \\
\text { steal }\end{array}$ \\
\hline Theft ex car & $\begin{array}{l}\text { To commit the theft of property from vehicles such as wheels and stereos, } \\
\text { along with personal items like bags, briefcases, laptops, mobile phones, CDs, } \\
\text { wallets and sunglasses, etc. }\end{array}$ \\
\hline Theft on the railways & To commit a theft on the railways \\
\hline Car theft & To commit the theft or attempted theft of a motor vehicle \\
\hline Fraud & $\begin{array}{l}\text { To deceive someone to damage him usually to obtain property or services } \\
\text { unjustly (example are flase advertising, identity theft, false billing, forgery of } \\
\text { dicuments or signatures, false isurance claim, investment frauds, etc.) }\end{array}$ \\
\hline Drugs & To produce and trade any drug product \\
\hline
\end{tabular}




\section{References}

Andersson, Tommy D., Rustad A. and Solberg Harry Arne (2004), "Local residents' evaluation of sports events," Managing Leisure, 9, p. 145-158.

Andranovich G., Burbank and M. J., Heying C. H. ( 2000), "Politics or Piecemeal Resistance?: Citizen Opposition to Olympic-Related Economic Growth," Urban Affairs Review; 35; p. 334-357.

Baloglu S., and Deccio C. (2002), "Non host Community Resident Reactions to the 2002 Winter Olympics: The Spillover Impacts," Journal of Travel Research; 41; p. 46-56.

Barker, M. (2004), “Crime and Sport Event Tourism. The 1999-2000 America's cup" in Sport Tourism: Interrelationship, Impacts and Issues, Brent W. Ritchie and Daryl Adair (Eds), pp. $174-191$.

Barker, M., Meyer D., Page and S. (2002), “Modelling tourism crime. The 2000 America's Cup," Annals of Tourism Research, 29-3, p. 762-782.

Becker, G. S. (1968), "Crime and punishment: an economic approach," The Journal of Political Economy, 76-2, p. 169-217

Bessant, J. (1993), "Young people and violence: a focus on schools ( a report of a pilot study), Second National Conference on Violence" convened by the Australian Institute of Criminology and held in Canberra, 15-18 June 1993

Billings, S. \& depken, C. A. II (2011). Sports Events and Criminal Activity: A Spatial Analysis. In R.T.. Jewell (ed.), Violence and Aggression in Sporting Contests: Economics, History and Policy. USA: Springer Publishing.

Block, M. K. and Heineke J.M. (1975), “A labour theoretic analysis of the criminal choice," American Economic Review, 65-3, p. 314-325.

Buonanno, P. and Leonida L. (2006), "Education and crime: evidence from Italian regions," Applied economics letter, 13, p. 709-713. 
Burns, J. P. A. and Mules, J. (1989), “An economic evaluation of the Adelaide Gran Prix ," in The planning and evaluation of hallmark events, p. 172-185.

Cherry T. L. and List J.A. (2002), "Aggregation bias in the economic model of crime," Economics Letters, 75, p. 81-86.

Chesney -Lind M. and Lind I. Y. (1986), "Visitors as victims. Crimes against tourists in Hawaii," Annals of Travel Research, 13-2, p. 167-191.

Clarke, A. (2004), "Evaluating mega events: a critical review," presented at the 3rd DeHaan Tourism Management Conference: The Impact and Management of Tourism - Related Events, Nottingham University Business School, p. 1-22.

Cook P. J. and Zarkin G. A. (1985), "Crime and the business cycle," Journal of Legal Studies, 15, PP. 115-128.

Cornwell, C. and Trumbull, W. N. (1994). "Estimating the Economic Model of Crime with Panel Data," The Review of Economics and Statistics, 76-2, pp. 360-366.

Dimanche, F. and Lepetic A. (1999), "New Orleans Tourism and Crime: A Case Study," Journal of Travel Research, 38, p. 19-23.

Dwyer L. and Mules T. (2005), "Public sector support for sport tourism events: the role of cost-benefit analysis," Sport in Society, 8, p. 338-355.

Ehrlich I. (1973), "Participation in illegitimate activities: a theoretical and empirical investigation," Journal of Political Economy, 81-3, p. 521-565.

Ehrlich I. (1996), "Crime, punishment, and the market for offenses," Journal of Economic Perspectives, 10-1, p. 43-67.

Fajnzylber, P., Lederman, D. and N. Loayza (2002), "What causes violent crime?," European Economic Review, 46, p. 1323-1357.

Freeman, R. B. (1996), "Why do so many young American men commit crimes and what might we do about it?," The Journal of Economic Perspectives, 10-1, p. 25-42. 
Freeman, R. B. (1999), "The economics of crime." Handbook of Labor Economics, 3, Ashenfelter O. and Card D. (Eds), p. 3530-3563.

Getz, D. (1997), Event Management and Event Tourism, New York, Cognizant, Elmsford.

Glaeser, E.L. (1999), An Overview of Crime and Punishment, Washington: World Bank. Mimeographed.

Hall, C. M. and H. J. Selwood (1989) “America's Cup Lost: Paradise Retained? The Dynamics of a Hallmark Tourist Event" in The Planning and Evaluation of Hallmark Events, G. J. Syme, B. J. Shaw, D. M. Fenton and W. S. Mueller, (eds.), pp. 103-118.

Hall, C. M. (1989), "Hallmark events and the planning process" in The planning and evaluation of hallmark events, J. Syme, B. J. Show, D.M. Fenton \& W.S. Mueller (eds.), Avebury, p. 20-39.

Hall, C.M. (1992), Hallmark Tourist Events: Impact, Management and Planning, London, Belhaven.

Hall, C.M. (1997), "Mega-events and their legacies" in Quality management in urban tourism, P.E. Murphy (eds.), Wiley, Chixhester, New York, pp. 91-102.

Harper D. W. (2001), "Comparing Tourists Crime Victimization," Annals of Tourism Research, 28-4, p. 1053-1056.

Hiller, H. H. (1989), “Impact and image: the convergence of urban factors in preparing for the 1988 Calgary Winter Olympics" in The planning and evaluation of hallmark events, p. 119-131.

Howsen Roy, M. and Jarrell, S. (1987), "Some determinants of property crime: economic factors influence criminal behaviour but cannot completely explain the syndrome," American Journal of Economics and Sociology, 46-4, p. 445-457. 
Howsen Roy M. and Jarrell S. (1990), "Transient Crowding and Crime: The More "Strangers" in an Area, the More Crime Except for Murder, Assault and Rape," American Journal of Economics and Sociology, 49-4, p. 483-494.

Imrohoroglu, A.., Merlo, A., Rupert, P. (2004), "What accounts for the decline in crime?," International Economic Review, 45-3, p. 707-729.

Levitt S. D. and Miles T. J. (2004), "Empirical Studies of Criminal Punishment," The handbook of Law and Economics, Polinsky A.M. and Steven Shavell S. (Eds.), p. 172.

Marselli, R. and Vannini, M. (1997) "Estimating a Crime Equation in the Presence of Organized Crime: Evidence from Italy," International Review of Law and Economics, 17, p. 89-113.

Marselli, R. and Vannini, M. (1999), Economia della criminalità: delitto e castigo come scelta razionale, UTET, Torino, pp. 376.

Marselli, R. and Vannini M., (2000) "Quanto incide la criminalità sui tassi di disoccupazione?," Rivista di politica economica, 5, pp. 273-299.

Neumayer, E. (2004), “The impact of Political Violence on Tourism. Dynamic cross section estimation," Journal of Conflict Resolution, 48-2, pp. 259-281.

McPheters, L. R. and Stronge W. B., (1974), "Crime as an environmental externality of tourism: Miami, Florida," Land Economics, 50-4, p. 288-292.

Oberwittler, D. (2004), “A Multilevel Analysis of Neighbourhood Contextual Effects on Serious Juvenile Offending: The Role of Subcultural Values and Social Disorganization," European Journal of Criminology, 1, p. 201-235

Ohmann S., Jones, I. and Wilkes, K. (2006), “The perceived social impacts of the 2006 Football World Cup on Munich Residents," Journal of Sport and Tourism, 11-2, p. $129-152$. 
Preuss, H. and Solberg, H. A. (2006), “Attracting Major Sporting Events: The Role of Local Residents," European Sport Mangement Quarterly, 6-4, p. 391-411.

Rees, D. I. and Schnepel , K. T. (2009), “College Football Games and Crime”, Journal of Sports Economics, 10-1; pp. 68-87.

Schneider, J.L. (2005), "Research note. The link between shoplifting and burglary," British Journal of Criminology, p. 1-7.

Sesnowitz, M. L. and. Hexter, J. L (1982), "Economic Determinants of Theft: Some Empirical Results," Public Finance Review, 10-4, pp. 489-498

Wooldridge, J.M. (2001) Econometric Analysis of Cross Section and Panel Data, The MIT Press Cambridge, Massachusetts, pp. 735

Wooldridge, J.M. (2002), Introductory econometrics. A modern approach, South-Western, pp. 805 .

\section{Notes}

\footnotetext{
${ }^{1}$ It is a database created by "LABORatorio R. Revelli" with data provided by INPS - the Italian Securitisation Programme of Social Security Contributions

${ }^{2}$ The source is "Quindici anni di statistiche provinciali," edited by Confindustria-IPI, Editore SIPI, Roma, 2000

${ }^{3}$ The fixed effects estimator (FE) uses a transformation to remove the unobserved effect $a_{i}$ prior to estimation. It is called the "within" estimator because it relies on variations within provinces rather than between provinces. Any time-constant explanatory variables are removed along with $a_{\mathrm{i}}$. This methodology has to be used if the unobserved fixed effects are correlated with the explanatory variables (Wooldridge, 2002). On the contrary the random effects estimator (RE) is attractive under the assumption that the unobserved effect is uncorrelated with all the explanatory variables. The random-effects estimator is more efficient than the fixed-effect as it uses both the cross-sectional (between) and time-series (within) variation of the data.
} 